Ankara Üniversitesi Türk Inkılâp Tarihi Enstitüsü Atatürk Yolu Dergisi

S 41, Mayts 2008, s. 89-104

\title{
Artvin Livası'nın Anavatan'a Katılıșı Sırasındaki Durumuna İlişkin Belgeler
}

\author{
Dr. Nurşen GÖK
}

\begin{abstract}
ÖZET
Bu makalede, yeniden Türk idaresine geçişinden sonraki dönemde Artvin Livası'nın konumuna ilişkin bazı belgeler üzerinde durulmaya çalıșılmıștır. Belgeler Ankara Üniversitesi Türk Inkalâp Tarihi Enstitüsü Arşivi'nde (TITEA) kayıtlı olarak bulunmaktadır. Yayınladığımı belgelerden birincisi 24 Mayls 1922 (24 Mayls 1338) tarihli olup, Türk idaresine geçişinden sonra Liva'da olussturulan nahiye teşkilatı ile ilgili bilgi vermektedir. İkinci belge, 19 Ekim 1921(19 Teşrin-i evvel 1337) tarihli Artvin Livası madenleri tahkikatına dair rapordur. Üçüncü belge ise Artvin'e bağlt ilçelerin bu dönemdeki nüfus yapısına ilişkindir. Elimizdeki son belge Elviye-i Selâse'de oluşturulan idari teşkilatlanmada yapılması önerilen düzenlemeye ilişkindir ve bu günkü Artvin ilinin idari yapısınin şekillenmesini de belirlemiş görünmektedir.
\end{abstract}

Anahtar Sözcükler: Artvin Livası, Elviye-i Selâse, nahiye teşkilatt.

\section{The Documents Which Relate to Artvin Liva After It Came Under the Turkish Control}

\section{ABSTRACT}

In this article, some documents which relate to Artvin Liva-after it kame under the Turkish control, are studied. These documents are currently registered at the Turkish Revolution History Institute. (TITEA) of Ankara University. The first published document, which is dated 24 May 1922 (24 May 1338) gives information about the local government in Liva after it came under Turkish control. The second document which is dated 19 October 1921 ( 19 Tesrin-i evvel 1337) gives information about the research carried out at Liva's mines. The third document is about the population statistics of that time in Artvin's provinces. The last document

\footnotetext{
* Ankara Üniversitesi Türk İnkılâp Tarihi Enstitüsü
} 
we have contains proposals in Evliye-i Selas (Kars, Ardahan, Batum Livas). This reorganisation appears to have shaped the government structures of the modern settlement of Artvin.

Key words: Artvin Liva, Elviye-i Selâse, The local organisation in Artvin, Artvin's metal resources.

Bu çalıșmada, yeniden Türk idaresine geçişinden sonraki dönemde Artvin Livası'nın konumuna ilişkin bazı belgeler üzerinde durulmaya çalışılacaktır ${ }^{1}$. Belgeler Ankara Üniversitesi Türk İnkılâp Tarihi Enstitüsü Arşivi'nde (TİTEA) kayıtlı olarak bulunmaktadır. Belgelerin bir kısmı yayınlanmıștır².

Değerlendireceğimiz dört belgeden birincisi 24 Mayıs 1922 (24 Mayıs 1338) tarihli olup, Türk idaresine geçişinden sonra Liva'da oluşturulan nahiye teşkilatı ile ilgili bilgi vermektedir. İkinci belge, 19 Ekim 1921(19 Teşrin-i evvel 1337) tarihli Artvin Livası madenleri tahkikatına dair rapordur. Üçüncü belge ise Artvin'e bağlı ilçelerin bu dönemdeki nüfus yapısına ilişkindir. Elimizdeki son belge Elviye-i Selâse'de oluşturulan idari teşkilatlanmada yapılması önerilen düzenlemeye ilişkindir ve bugünkü Artvin ilinin idari yapısının şekillenmesini de belirlemiş görünmektedir.

Bilindiği üzere 1877-1878 Osmanlı-Rus Savaşı sonrasında 3 Mart 1878 tarihinde imzalanan Berlin Antlaşması hükümleri gereğince Kars, Ardahan ve Batum savaş tazminatı olarak Rusya'ya terk edilmişti. Bu antlaşma ile Batum Sancağı'na bağlı bulunan Artvin, Ardanuç, Borçka, Şavşat ilçelerini içine alan yerler ve Hopa'dan Kemalpaşa kesimi Rusya'ya bırakılmıştı. Daha sonra Gümrü (2 Aralık 1920) ve Moskova (16 Mart 1921) antlaşmalarıyla Türkiye'ye terk edilen bu mahallerde ise Artvin, Ardahan ve Kars livaları oluş̧urulmuştu ${ }^{3}$.

Kars Sancağı, Çarlık yönetiminde Zakavkazya genel valiliğine bir oblast (vilayet) olarak katılmıştı. Zakavkazya bölgesinin başkenti Tiflis’ti.

\footnotetext{
${ }^{1}$ Belgelerin varlığından beni haberdar eden doktora tez hocam Sayın Prof. Dr. Musa Çadırcı'ya teşekkürü borç bilirim.

${ }^{2}$ Prof.Dr. Musa Çadırcı, "Artvin Tarihine Ilişskin Belgeler", Bizim Atabarı, Turizm Tanıtım Kültür Sanat Dergisi, Ankara, sayı 18, 2006, s.11-14; "Artvin Tarihine Ilişskin Belgeler II", Bizim Atabarı, Turizm Tanttım Kültür Sanat Dergisi, sayı 19, Ankara, 2006, s.24-27.

37 Temmuz 1337 (1921) tarih ve 133 numaralı Anavatan'a iltihak eden arazide icra edilecek teşkilatı mülkiyeye dair kanun'un birinci maddesi “Anavatan'a iltihak eden mahallerde Artvin, Ardahan, Kars livalan teşkil ve Iğdır ve Kulp kazalan Beyazıt Sancağı'na raptedilmiştir" demektedir. İkinci maddede Artvin Sancağı'nın Şavşat ve Borçka kazalanndan oluştuğu belirtilmektedir. TBMM Kavanîn Mecmuası, Cilt 1, Ankara, 1943, s.148.
} 
Zakavkazya genel valiliği Çarlık niyabetiydi. Genel valilik birçok Guberniyalar (vilayet) ve Oblastlardan (2.derece bölge) meydana gelmekteydi. Guberniyalar; Tiflis, Kutay, Yelizavetpol, Bakü, Erivan, Çernomorks, Stavropol'dü. Kars Sancağı, genişletilerek ve Kuban, Tersk ve Dağıstan gibi doğrudan genel valiliğe bağlı bir oblast haline getirilmişken, Batum ve Artvin Sancakları Tiflis Guberniya'sına bağlanmıştı ${ }^{4}$.

İdareleri altında bulundurdukları kırk yıl süresince Ruslar üç sancak bölgesini tümgeneral rütbesinde iki askeri valilik halinde (Kars ve Batum) idare ettiler. Kars'ta ve Batum'da tümgeneral rütbesinde birer askeri vali bulunurken, ilçelerde de albay rütbesinde veya bu rütbe karşılığında bir askeri kaymakam (naçalik) bulunuyordu. Bucaklarda halk tarafindan seçilen bir bucak müdürü (istarşın) bulunduruldu. Köylerde muhtarlar görev yapmakta sekiz köyün ise bir baş muhtarı (klava) bulunmaktaydı ${ }^{5}$.

Bolșevik Devrimi'nin 1917'de patlak vermesinden sonra Osmanlı Devleti ve Rusya arasında 3 Mart 1918 tarihinde imzalanan Brest-Litovsk Antlaşması hükümleri gereğince yapılan halk oylaması sonucunda Kars, Ardahan ve Batum, Osmanlı İmparatorluğu'na bağlandı. Ancak 30 Ekim 1918 Mondros Bırakışmasıyla Osmanlı kuvvetlerinin çekildiği bölgeler arasında Artvin de bulunmaktaydı. İngilizlerin 17 Aralık 1918 tarihinde işgal ettikleri Artvin'den Nisan 1920 tarihinde çekilmeleri sonucunda bölge Gürcülerin denetimi altına girdi. Gürcü işgali 1921 başlarına kadar devam etti.

Artvin ve çevresinin, 1921 yılında, Anavatan'a katılışından sonra Artvin ve Şavşat Kazaları 4,5 ay süreyle Ardahan Sancağı'na bağlandı. Bu dönemde Yusufeli (Kiksim) Kazası Erzurum, Hopa Kazası da Rize Sancakları sınırları içindeydi. 7 Temmuz 1921 tarih ve 133 numaralı kanunla Artvin liva oldu. Ardahan'dan Şavşat Kazası alınarak Artvin'e bağlandı ${ }^{6}$.

Ele alacağımız ilk belge olan, Artvin Mutasarrıf vekili tarafından 24 Mayıs 1922(24 Mayıs 1338) tarihinde Elviye-i Selâse Tahkik ve Tetkik Heyeti Başkanlığı'na cevap yazısı olarak gönderilen Artvin Livası nahiye teşkilatının kuruluşuna dair rapor, bize Türk yönetimine geçtikten sonra Liva'da oluşturulan nahiye teşkilatı hakkında bilgi vermektedir?

\footnotetext{
${ }^{4}$ İlber Ortaylı, "Çarlık Rusyası Yönetiminde Kars", Osmanlı İmparatorluğu'nda İktisadi ve Sosyal Değişim, Makaleler I, Ankara, 2000, s.400.

${ }^{5}$ Halit Özdemir, Artvin Tarihi, II. Baskı, Artvin, 2002, s. 206

${ }^{6}$ Yurt Ansiklopedisi, Cilt 2, Anadolu Yayıncılık, İstanbul, 1982, s. 898-908,

${ }^{7}$ Ankara Üniversitesi, Türk İnkılâp Tarihi Enstitüsü Arşivi (TiTEA) Kutu (K) 96 Gömlek (G)12 Belge (B)12.
} 
Söz konusu rapora göre Artvin Livası'nda nahiye teșkilatı 1922 yılı mart ayından itibaren uygulanmaya başlanmıştır. Teşkilatın Rus idaresi döneminden kalmamış olup tamamen halkın ihtiyaç ve arzusuna göre oluşturulduğu, nahiye idarelerinin Artvin Livası halkının irade ve arzusunun resmi bir şekilde kabulü ve uygulamasından ibaret olduğu raporda özellikle belirtilmektedir. Buna göre bir grup halinde birleşmek isteyen köyler bir araya getirilip birleştirilerek bir nahiye teşkil edilmiştir. Nahiye müdürü ve nahiye azalıklarına, nahiye bölgesi dâhilinde oturmakta olan yirmi yaşında ve yirmi yaşını geçmiş erkek nüfusun seçtiği çoğunluğu elde eden kişi tayin edilmiştir.

Nahiye bütçeleri, nahiye bölgesinde oturmakta olan köy muhtarları ve ihtiyar heyetleriyle nahiye azalarından oluşan nahiye şuraları tarafından düzenlenmiş ve her köy muhtar ve ihtiyar heyeti, bütçenin düzenlenmesinden önce mensup olduğu köy ahalisiyle fikir alış verişinde bulunarak onların onayını almıștır.

Müdüriyet maaşları bazı nahiyelerde bin kuruştur. Bazılarında bin beş yüz, iki bin, üç bin kuruşa kadar yükselmektedir. Şuralar tarafından bir kısım nahiyelerin bir müdürle idaresi uygun bulunduğu halde bazı nahiye şuraları bütçelerinden bir kâtip, bazıları da bir müftü gideri ilave etmişlerdir.

Nahiye teşkilatı ve nahiye bütçeleri, teşkili takiben Vilayet Umumi Meclisi'nin ve daha sonra Dâhiliye Vekâleti'nin görüşlerine arz edilmek üzere, usulüne göre idare meclisi tarafından onaylanmıştır. Düzen ve muamelenin selameti için nahiye bütçelerinin tahsilât ve harcamaları Liva özel idare bütçesine dâhil edilerek Liva muhasebesi tarafından yerine getirilecektir.

Bu yeni teşkilatlanma, Büyük Millet Meclisi'nden çıkarılan 7 Temmuz 1921 tarih 133 numaralı "Ana vatan'a iltihak eden arazide icra edilecek teşkilat-1 mülkiyeye dair kanun"un dördüncü maddesi uyarınca yürütülmüștür. Söz konusu kanun maddesi "Evliye-i Selâse'de Teşkilat-1 esasiye kanununa tevfikan nevâhî teșkilatı icra edilinceye kadar nevâhî müdüranı kemâfi's-sâbık ahali tarafindan intihab olunur" demektedir. ${ }^{8}$

${ }^{8}$ TBMM Kavanîn Mecmuası, Cilt 1, Ankara, 1943, s.148. Bu madde ile ilgili Büyük Millet Meclisi'nde yapılan tartışmalarda, maddenin bu şekilde düzenlenmesine muhalif olanların üzerinde durdukları nokta nahiye müdürünün halk tarafindan seçilecek olmasının daha önce kabul edilmiş olan Teşkilat-1 Esasiye Kanununa uygun olmamasıdır. 7 Şubat 1921 (1337) tarihli Teşkilat-1 esasiye kanunu'nda nahiye teşkilatına ait bölümü ise şu şekilde düzenlenmiştir: 16. madde: Nahiye hususi hayatında muhtariyeti haiz bir manevi şahsiyettir. 17. madde: Nahiyenin bir şûrası, bir idare heyeti ve bir de müdürü vardır. 18. madde: Nahiye şûrası, nahiye halkınca doğrudan doğruya müntehab azadan terekküb eder. 19. madde: İdare heyeti ve nahiye müdürü, nahiye şurası tarafindan intihap olunur. 20. madde: Nahiye şûrası ve 
Yapılan bu yeni düzenlemenin Liva'ya sağladığı faydalardan raporda şu şekilde bahsedilmektedir:

$\mathrm{Bu}$ teşkilat sayesinde Liva'nın her tarafında inzibat ve asayişin sağlanmıștır, köylülerin hiçbir tahsildar ve jandarma tarafından rahatsız edilmeksizin emval-i umumiye ve hususiye tahsilâtının \%98'e yükselmiştir. Nahiye düzenlemesiyle mevcut livaların en küçügü ve halen en fakiri bulunan Artvin Livası'nda mükemmel bir maarif programı merkez ve nahiyelerde uygulamaya konulmuştur'.

Üç kazadan oluşan Artvin Livası'nın masraf bütçesi rapora göre 14 bin liradır. Nahiye teşkilatının kurulmasına olanak sağlayan bu kanun sayesinde halkla hükümet arasındaki ayrılığın sona ererek Büyük Millet Meclisi'nin hükümet teşkiline uygun bir şekilde halkın kendi kendini idare ettiğini anlamaya başladığı, halkın da hükümetin de aracıların gereksiz vekâlet ve vesayetinden kurtulduğu raporda vurgulanmaktadır.

Rapor, kanunların halkın ihtiyaçlarına uygun olması durumunda elde edilebileceklere Artvin nahiye teşkilatının iyi bir örnek olduğu belirtilerek ve kanunları, idare teşkilatını halkın memleket ihtiyaç ve arzularına yaklaştırmak için hiç olmazsa vilayet ve livalarla ilgili bütçe ve teşkilatın bu ihtiyaçlarla karşı karşıya gelen mahaldeki bir heyet tarafından hazırlanması temennisiyle bitirilmektedir.

İkinci belge, Artvin Mutasarrıflığı tarafından İktisat, Maliye, Dâhiliye vekâletleriyle Şark Cephesi Kumandanlığına gönderilen 19 Ekim 1921(19 Teşrin-i evvel 1337) tarihli Artvin Livası madenleri tahkikatına dair rapordur ${ }^{10}$.

Söz konusu rapora göre Liva dâhilinde Murgul nahiyesiyle Kuvarshan (Bakırköy) ve Hod karyeleri civarında üç bakır fabrikası mevcut olup bunlardan birincisi Borçka diğer ikisi merkez kazası dâhilinde bulunmaktadır. Bu fabrikaların en büyüğü Murgul ve en küçüğü Hod madenidir. Her iki maden savaş esnasında İngilizler ve Gürcüler ve kısmen

idare heyeti kazaî, iktisadî ve malî selahiyeti haiz olup bunlann derecatı kavanini mahsusa ile tayin olunur. 21. madde: Nahiye bir veya birkaç köyden mürekkep olduğu gibi bir kasaba da bir nahiyedir.(TBMM Kavanîn Mecmuası, cilt 1, Ankara, 1943 s.85). Tartışmalar sonunda henüz Divan Riyaseti'nde tartışılacak olan söz konusu kanunun icrasına kadar bölgede nahiye müdürlerinin halkın alışkın olduğu usul gereğince, halk tarafından seçilmesi karan alınmıștır. (TBMM Zabut Ceridesi, Devre: I İçtima: 2, TBMM Matbaası, Ankara, 1958, s. 172-180).

${ }^{9}$ Artvin Livası'nın Mayıs 1922 yılındaki eğitim ve öğretim durumu ile ilgili Mutasarnıf Vekili İsmet imzasıyla Elviye-i Selâse Tahkik ve Tetkik Heyeti Başkanlığı'na gönderilen rapor (TITE A K.98 B.18) için bkz: Musa Çadırcı, Bizim Ataban, Turizm Tamıtım Kültür Sanat Dergisi, Say1: 18, Ankara, 2006, s.11,12.

${ }^{10}$ TITEA K.96 G.13 B.13 (1-3). 
de ahali tarafında pek çok tahribata uğramaları nedeniyle kendilerinden yararlanılmayacak durumdadırlar. Yalnız Murgul fabrikasının tamiri tahminen bir milyon lira kadar meblağı gerektirmektedir. Halen gerek liva ve gerekse Kafkasya dâhilindeki bakır madenlerinden yalnız Kuvarshan fabrikası faaliyet gösterebilecek bir durumda ve tamamıyla bayındır haldedir. Alman tebaasından Schemi Biraderlerin tasarrufu altında olup bir vekil tarafından idare edilen bu fabrika, yedi yıl önce inşaatını tamamlamış ve bakır ihracatına başlamıştır. Madenin imtiyazname ve resmi evrakının Rusça ve Fransızca birer suretiyle fabrikaya ait binaların Rusça cetveli ve madenin haritası incelenmek üzere İktisat Vekâleti'ne gönderilmiştir.

Eski idare zamanındaki kanun hükümlerine göre fabrikanın hükümete 13.233 Ruble'den rayice göre 7.938 Lira akar ve bir köy vermesi gerektiği, arazi vergisiyle fabrika faaliyete geçtiği zaman muayyen tarifeye uygun olarak alınması gereken orman vergisi ve memur ve müstahdemlerin hesabına ödenmesi gereken temettü vergilerinin dahi bu meblağa ilave edilmesi gerektiği raporda belirtilmektedir.

Rapora göre madenin bileşikleri arasındaki arsenik bileșiği bitki ve ağaçlara zarar verdiği için fabrika, ancak kış aylarında çalışabilecektir. Ziraat, ticaret ve hayvanattan mahrum olan Liva'nın servetini hemen hemen bu madenler oluşturduğu için fabrikalar çalıştırılmazsa ne Liva'nın masrafları için önemli bir gelir ne de halk için bir servet bulmak mümkündür.

Hâlihazırda fabrikanın elinde 50.000 kiloya yakın hazır bakır mevcuttur ve çalıștığı kış aylarında da 150.000 kiloya kadar bakır üretilebilecektir.

Gerek hükümete ait vergilerin ödenmesi ve gerekse fabrikanın kış aylarında çalışmasını sağlamak için hazırlıkların tamamlanması için elde bulunan ve üretilecek bakırın ihraç ve satışı ve fabrikaya gereken gaz yağı, kok kömürü, benzin, mazot, makine yağının ithali hususunda izin verilmesi ve kolaylık gösterilmesi talep edilmekte olduğundan hükümet ve ordu için bakıra ihtiyaç varsa hazinenin taleplerine karşılık olmak üzere miktarının tayin ve keyfiyetin bir an önce bildirilmesi raporda rica edilmektedir.

Diğer kanunlar gibi madenlere ait de Liva'da hiçbir kanun kitabı ve hiçbir emir olmadığından şimdilik Rus idaresi zamanındaki cari vergilerin ödenmesine devam edilmesi ve fenni memur ve müstesna olmak üzere amelelerin Türk uyruğunda olmaları Maden Müdüriyeti'ne tebliğ edilmiştir.

Rapor, hükümet tarafından konulmasına gerek görülecek şart ve esaslar ve madenlerle ilgili kanun ve nizamların önemli maddeleri ve maliyesi 
hakkında Liva'nın telgrafla aydınlatılması ve Liva'ya yeni ve eski düsturlardan birer takım gönderilmesini ricasıyla sona ermektedir.

Rapordan anlaşıldığı üzere, bölgedeki bakır cevheri Rus yönetimi esnasında işletilmeye açılmış durumdadır. Endüstriye yönelik bu madenin Kars bölgesinde de bulunmakla beraber, bu bölgede Rus idaresi döneminde işletilmediğini biliyoruz ${ }^{11}$.

Ele alacağımız diğer bir belge Artvin Livası'nın kasaba, nahiye ve köylerinin nüfusu ile ilgilidir. Artvin mutasarrıfı tarafindan Haziran 1922 (Haziran 1338) tarihinde düzenlenen cetvelde ${ }^{12}$ Merkez Liva ile Borçka, Şavşat kazalarına bağlı nahiyelerin nüfusları hane kadın ve erkek olarak belirtilmiştir. Nüfus sayımının hangi millete mensup olunduğunun dikkate alınarak yapıldığı görülmektedir. Buna göre bu tarihte hangi sayıda Türk, Ermeni ve Gürcü'nün sakin bulunduğu izlenebilmektedir.

\section{Merkez Liva'ya Bağlı Ardanuç Nahiyesi ${ }^{13}$.}

\begin{tabular}{|l|l|l|l|l|l|}
\hline Köy ismi & Hane & Milleti & Kadın & Erkek & Toplam \\
\hline $\begin{array}{l}\text { Ardanuç } \\
\text { Merkez İslam } \\
\text { Mahallesi }\end{array}$ & 15 & Türk & 100 & 60 & 160 \\
\hline $\begin{array}{l}\text { Ardanuç } \\
\text { Merkez } \\
\text { Ermeni } \\
\text { Mahallesi }\end{array}$ & 25 & Ermeni & 62 & 38 & 100 \\
\hline Bice Karyesi & 69 & Türk & 128 & 133 & 261 \\
\hline Mazalahet & 21 & " & 35 & 46 & 81 \\
\hline Basa & 36 & " & 59 & 55 & 114 \\
\hline Cuğo & 11 & " & 15 & 21 & 36 \\
\hline Ançkora & 39 & " & 168 & 202 & 380 \\
\hline Obicala & 7 & " & 10 & 11 & 21 \\
\hline Anç & 63 & 171 & 99 & 270 \\
\hline $\begin{array}{l}\text { Samuskar-1 } \\
\text { Ulya }\end{array}$ & 75 & " & 116 & 131 & 247 \\
\hline $\begin{array}{l}\text { Samuskar-1 } \\
\text { Süfla }\end{array}$ & 48 & " & 194 & 223 & 417 \\
\hline Nörgiyal & 27 & “ & 73 & 91 & 164 \\
\hline Cidil & 87 & " & 203 & 255 & 458 \\
\hline Petoban & 22 & " & 61 & 65 & 126 \\
\hline Göraşet & 62 & 198 & 211 & 409 \\
\hline Ustamel & 10 & " & 20 & 28 & 48 \\
\hline
\end{tabular}

\footnotetext{
${ }^{11}$ Ortayli, agm., s.407.

${ }^{12}$ TITEA: K.96 G.10 B.10.

${ }^{13}$ TITEA: K.96 G.10 B.10-3
} 


\begin{tabular}{|c|c|c|c|c|c|}
\hline Karsniya & 39 & $"$ & 122 & 134 & 256 \\
\hline Anagert & 88 & “ & 198 & 200 & 398 \\
\hline Solyana & 16 & " & 53 & 51 & 104 \\
\hline Kontrom & 17 & $"$ & 50 & 45 & 95 \\
\hline Ahiza & 23 & 4 & 38 & 35 & 73 \\
\hline Miker & 13 & $"$ & 23 & 27 & 50 \\
\hline Haravul & 18 & 4 & 34 & 42 & 76 \\
\hline Havet & 30 & $"$ " & 46 & 52 & 98 \\
\hline Aharşit? & 30 & $" 6$ & 48 & 56 & 104 \\
\hline Şuvagulavur? & 20 & $" 6$ & 32 & 46 & 78 \\
\hline Mezegil & 27 & $" 6$ & 47 & 53 & 100 \\
\hline Diyagarmuç & 35 & " & 64 & 59 & 123 \\
\hline Rabat & 8 & “ & 20 & 24 & 44 \\
\hline Gümüșhane & 81 & $"$ & 143 & 152 & 295 \\
\hline Longothev & 41 & “ & 84 & 95 & 179 \\
\hline Usot & 23 & $“$ & 36 & 52 & 88 \\
\hline Gülice & 10 & $"$ & 17 & 22 & 39 \\
\hline Heva & 9 & $" 6$ & 15 & 13 & 28 \\
\hline Eşkinar & 7 & $“$ & 10 & 17 & 27 \\
\hline Kaşıkçı & 10 & " & 20 & 20 & 40 \\
\hline Hamagirvet & 37 & $"$ & 61 & 74 & 135 \\
\hline Vardayla & 31 & $"$ & 49 & 63 & 122 \\
\hline Unushev & 52 & “ & 97 & 95 & 192 \\
\hline Güleşin & 62 & $"$ & 109 & 118 & 227 \\
\hline Varthel & 3 & " & 2 & 4 & 6 \\
\hline Sahre & 29 & " & 50 & 46 & 96 \\
\hline Kilarcet & 41 & “ & 73 & 82 & 155 \\
\hline Aravet & 3 & " & 5 & 5 & 10 \\
\hline Cara & 5 & $"$ & 12 & 9 & 21 \\
\hline Camandar & 8 & " & 14 & 19 & 33 \\
\hline Suagara & 24 & “ & 32 & 45 & 77 \\
\hline Ortis & 14 & " & 22 & 31 & 53 \\
\hline Kapdahor & 77 & " & 154 & 163 & 317 \\
\hline Danzot & 111 & " & 207 & 329 & 536 \\
\hline Zegerya & 23 & $"$ & 38 & 62 & 100 \\
\hline Sagara & 26 & $"$ & 49 & 49 & 98 \\
\hline Hertüvis & 17 & " & 27 & 29 & 56 \\
\hline Yekun & 1084 & & 3719 & 4090 & 7809 \\
\hline
\end{tabular}


Merkez Liva'ya Bağlı Berta Nahiyesi ${ }^{14}$ :

\begin{tabular}{|l|l|l|l|l|l|}
\hline Köy ismi & Hane & Milleti & Kadın & Erkek & Toplam \\
\hline Berta & 114 & Türk & 363 & 396 & 759 \\
\hline Porta & 15 & " & 34 & 47 & 81 \\
\hline Obze & 10 & " & 39 & 26 & 65 \\
\hline $\begin{array}{l}\text { Sagal-1 } \\
\text { teze }\end{array}$ & 19 & " & 51 & 67 & 118 \\
\hline Daba & 4 & " & 8 & 4 & 12 \\
\hline Cimerk & 7 & " & 15 & 15 & 30 \\
\hline Dolishane & 15 & " & 32 & 25 & 57 \\
\hline Yekun & 184 & & 542 & 580 & 1122 \\
\hline
\end{tabular}

Merkez Liva'ya Bağı Sirya Nahiyesi ${ }^{15}$

\begin{tabular}{|l|l|l|l|l|l|}
\hline Köy ismi & Hane & Milleti & Kadın & Erkek & Toplam \\
\hline Sirya & 80 & Türk & 168 & 162 & 330 \\
\hline Orçuk & 69 & " & 126 & 142 & 272 \\
\hline Işhabor & 48 & " & 84 & 90 & 174 \\
\hline Urcan & 13 & " & 24 & 21 & 45 \\
\hline Buslet & 23 & " & 38 & 33 & 71 \\
\hline Ağara & 22 & " & 30 & 35 & 65 \\
\hline Kiyashane & 16 & " & 24 & 25 & 49 \\
\hline Hizor & 46 & " & 75 & 84 & 109 \\
\hline Hodliyan & 103 & " & 237 & 254 & 491 \\
\hline Hod-1 süfla & 18 & “ & 27 & 45 & 72 \\
\hline Yekun & 438 & & 833 & 695 & 1528 \\
\hline
\end{tabular}

Şavşat Kazası Merkez Nahiyesi ${ }^{16}$ :

\begin{tabular}{|l|l|l|l|l|l|}
\hline Köy ismi & Hane & Milleti & Kadın & Erkek & Toplam \\
\hline Zendeba & 48 & Türk & 176 & 154 & 330 \\
\hline Morğel & 56 & " & 200 & 173 & 373 \\
\hline Verhunal & 60 & " & 163 & 271 & 434 \\
\hline Çartulet & 33 & “ & 124 & 105 & 229 \\
\hline Hantuşet & 51 & “ & 149 & 153 & 302 \\
\hline Sırasinkot & 56 & “ & 153 & 170 & 323 \\
\hline Muhoban & 29 & " & 105 & 97 & 202 \\
\hline Ankliya & 91 & " & 280 & 284 & 564 \\
\hline Samcel & 29 & “ & 75 & 68 & 143 \\
\hline Sorsel & 41 & " & 143 & 129 & 272 \\
\hline Vanta & 16 & “ & 41 & 46 & 87 \\
\hline
\end{tabular}
${ }^{14}$ TITEA: K.96 G.10 B.10-2
15 TITEA: K.96 G.10 B. 10-2
${ }^{16}$ TITEA: K.96 G.10 B.10-6. 


\begin{tabular}{|l|l|l|l|l|l|}
\hline Zoret & 13 & “ & 35 & 28 & 63 \\
\hline Sinkot & 62 & “ & 192 & 154 & 346 \\
\hline Morohoz & 33 & “ & 100 & 107 & 207 \\
\hline Mokta & 71 & “ & 223 & 240 & 463 \\
\hline Seslavur & 42 & “ & 122 & 120 & 242 \\
\hline Satlel & 64 & “ & 160 & 174 & 334 \\
\hline Kötatrilis & 102 & “ & 276 & 320 & 596 \\
\hline Soporo & 31 & “ & 93 & 99 & 192 \\
\hline Ahaldaba & 200 & “ & 540 & 623 & 1163 \\
\hline Kuçen & 112 & “ & 363 & 337 & 700 \\
\hline Mamanaliz & 158 & “ & 415 & 378 & 793 \\
\hline Turmanize & 16 & “ & 46 & 53 & 99 \\
\hline Gürnatel & 13 & “ & 65 & 63 & 128 \\
\hline Rabat & 5 & “ & 11 & 7 & 18 \\
\hline Toplam & 1442 & & 4250 & 4303 & 8603 \\
\hline
\end{tabular}

Şavşat Kazası'na Bağıı İmerhev Nahiyesi ${ }^{17}$.

\begin{tabular}{|c|c|c|c|c|c|}
\hline Köy ismi & Hane & Milleti & Kadın & Erkek & Toplam \\
\hline Skalsimer & 125 & Gürcü-İslam & 427 & 444 & 871 \\
\hline Diyoban & 103 & $" 6$ & 333 & 366 & 699 \\
\hline İvet & 30 & $"$ & 103 & 112 & 215 \\
\hline İbhirevil & 75 & “ & 272 & 271 & 543 \\
\hline Hevzril? & 46 & $"$ & 168 & 184 & 352 \\
\hline Bazgiret & 45 & $"$ & 145 & 137 & 282 \\
\hline Zakiyet & 43 & " & 139 & 137 & 276 \\
\hline Daba & 44 & " & 150 & 129 & 279 \\
\hline Ziosi & 12 & " & 57 & 51 & 108 \\
\hline Ube & 27 & $"$ & 94 & 108 & 200 \\
\hline $\begin{array}{l}\text { Zetilit } \\
\text { Ağara }\end{array}$ & 96 & " & 333 & 342 & 675 \\
\hline Morivan & 98 & " & 333 & 343 & 679 \\
\hline Cihor & 100 & " & 398 & 381 & 779 \\
\hline $\begin{array}{l}\text { Ukret? } \\
\text { Manatba }\end{array}$ & 37 & $"$ & 112 & 107 & 219 \\
\hline Çihishev & 84 & " & 247 & 281 & 528 \\
\hline Ustamis & 38 & " & 146 & 150 & 296 \\
\hline $\begin{array}{l}\text { Pençekor } \\
\text { Rabatı } \\
\text { İroğlu }\end{array}$ & 10 & $"$ & 19 & 18 & 37 \\
\hline Hayta & 13 & $"$ & 57 & 42 & 99 \\
\hline Yekun & 1026 & & 3531 & 3603 & 7134 \\
\hline
\end{tabular}

${ }^{17}$ TITEA: K.96 G.10 B.10-7. 
Savșat Kazası'na Bağı̆ı Merya Nahiyesi ${ }^{18}$

\begin{tabular}{|l|l|l|l|l|l|}
\hline Köy ismi & Hane & Milleti & Kadın & Erkek & Toplam \\
\hline Simzebir & 105 & Türk & 285 & 315 & 600 \\
\hline Cuvareb & 116 & " & 371 & 389 & 760 \\
\hline Zizvet & 73 & " & 223 & 245 & 468 \\
\hline Garkulob & 145 & " & 485 & 517 & 1002 \\
\hline Cinal & 175 & " & 558 & 598 & 1156 \\
\hline Sihıya & 104 & " & 296 & 322 & 618 \\
\hline Suloban & 214 & " & 645 & 707 & 1352 \\
\hline Merya & 91 & " & 283 & 292 & 575 \\
\hline Dabazurul & 77 & " & 225 & 205 & 430 \\
\hline $\begin{array}{l}\text { Süles-i } \\
\text { ülya }\end{array}$ & 44 & & 137 & 129 & 266 \\
\hline Süles & 44 & " & 135 & 137 & 272 \\
\hline Balvana & 51 & " & 155 & 154 & 309 \\
\hline Savket & 35 & “ & 75 & 91 & 166 \\
\hline Vel & 117 & 301 & 276 & 577 \\
\hline Tibet & 156 & " & 445 & 404 & 849 \\
\hline Dabagetil & 27 & 65 & 74 & 139 \\
\hline Yekun & 1574 & & 4684 & 4855 & 9539 \\
\hline
\end{tabular}

Borçka Kazası Merkez Nahiyesi ${ }^{19}$ :

\begin{tabular}{|c|c|c|c|c|c|}
\hline Köy ismi & Hane & Milleti & Kadın & Erkek & Toplam \\
\hline $\begin{array}{l}\text { Merkez } \\
\text { Borçka } \\
\text { Mahallesi }\end{array}$ & 26 & Gürcü-İslam & 50 & 80 & 130 \\
\hline $\begin{array}{l}\text { Arçivet } \\
\text { Köyü }\end{array}$ & 1 & $"$ & & 1 & 1 \\
\hline Cikavet & 1 & " & & 1 & 1 \\
\hline $\begin{array}{l}\text { Memanet-i } \\
\text { Ülya }\end{array}$ & 10 & Laz & 31 & 27 & 58 \\
\hline $\begin{array}{l}\text { Memanet-i } \\
\text { Süfla }\end{array}$ & 3 & " & 6 & 6 & 12 \\
\hline Pançuret & 4 & " & 5 & 7 & 12 \\
\hline Kostanet & 4 & " & 12 & 12 & 24 \\
\hline Vakura & 5 & " & 10 & 10 & 20 \\
\hline Düzköy & 25 & $"$ & 44 & 55 & 99 \\
\hline Makrit & 4 & “ & 12 & 10 & 22 \\
\hline Cat & 1 & $"$ & 1 & 2 & 3 \\
\hline Başköy & - & - & - & - & - \\
\hline Valaşin & 5 & Gürcü-İslam & 16 & 17 & 33 \\
\hline Aravet & 6 & " & 13 & 15 & 28 \\
\hline
\end{tabular}

${ }^{18}$ TITEA: K.96 G. 10 B.10-6.

${ }^{19}$ TITEA: K.96 G. 10 B. 10-4 


\begin{tabular}{|l|l|l|l|l|l|}
\hline Samherov & 2 & “ & 6 & 6 & 12 \\
\hline Banagana & 2 & " & 3 & 5 & 8 \\
\hline Suahav & 10 & " & 15 & 27 & 42 \\
\hline Ohurçin & 8 & " & 20 & 21 & 41 \\
\hline Senates & 9 & " & 25 & 22 & 47 \\
\hline Deviskal & 64 & " & 108 & 194 & 352 \\
\hline Bagin & 45 & “ & 80 & 93 & 1738 \\
\hline
\end{tabular}

\section{Borçka Kazası'na Bağlı Maradid Nahiyesi ${ }^{20}$ :}

\begin{tabular}{|l|l|l|l|l|l|}
\hline Köy ismi & Hane & Milleti & Kadın & Erkek & Toplam \\
\hline Maradid & 60 & Gürcü-İslam & 143 & 137 & 280 \\
\hline Kadaphiya & 22 & " & 53 & 46 & 99 \\
\hline Morçivet & 5 & " & 13 & 13 & 26 \\
\hline $\begin{array}{l}\text { Yenimahalle } \\
\text { Köyü }\end{array}$ & 4 & “ & 12 & 14 & 26 \\
\hline Beznevur & 24 & “ & 51 & 52 & 103 \\
\hline Suban & 23 & " & 49 & 68 & 117 \\
\hline Çenkavur & 12 & " & 24 & 29 & 53 \\
\hline Sabasur & 22 & " & 50 & 69 & 119 \\
\hline Gurgavul & 5 & " & 15 & 14 & 23 \\
\hline Oğlavur & 16 & “ & 33 & 34 & 67 \\
\hline Gerdaș & 4 & " & 6 & 7 & 13 \\
\hline Hensekane & 20 & “ & 30 & 44 & 74 \\
\hline Kırnat & 27 & “ & 71 & 90 & 161 \\
\hline Zeduban & 13 & " & 20 & 33 & 53 \\
\hline Kinsihuret & 6 & “ & 11 & 12 & 23 \\
\hline Kuplet & 13 & 43 & 47 & 90 \\
\hline Yekun & 276 & & 624 & 709 & 1333 \\
\hline & & & & \\
\hline
\end{tabular}

\section{Borçka Kazası'na Bağıı Maçahalis Nahiyesi ${ }^{21}$}

\begin{tabular}{|l|l|l|l|l|l|}
\hline Köy ismi & Hane & Milleti & Kadın & Erkek & Toplam \\
\hline Hırtovlis? & 20 & $\begin{array}{l}\text { Gürcü- } \\
\text { İslam }\end{array}$ & 53 & 65 & 118 \\
\hline Kavtareti? & 24 & " & 66 & 70 & 136 \\
\hline Zedeveka & 31 & “ & 118 & 109 & 227 \\
\hline Efrad & 19 & “ & 70 & 90 & 160 \\
\hline Kuvabistav & 23 & “ & 75 & 73 & 148 \\
\hline Mindiyeti & 37 & " & 145 & 181 & 326 \\
\hline Iremeti? & 22 & “ & 52 & 66 & 118 \\
\hline Akriya & 29 & " & 120 & 127 & 247 \\
\hline Toplam & 205 & & 699 & 781 & 1480 \\
\hline
\end{tabular}

${ }^{20}$ TITEA: K.96 G.10 B. 10-5.

${ }^{21}$ TITEA: K.96 G.10 B. 10-5. 


\section{Borçka Kazası'na Bağıı Murgul Nahiyesi ${ }^{22}$}

\begin{tabular}{|c|c|c|c|c|c|}
\hline Köy İsmi & Hane & Milleti & Kadın & Erkek & Toplam \\
\hline Zansul & 30 & Gürcü-İslam & 82 & 87 & 169 \\
\hline Kabarcet & 10 & " & 27 & 26 & 53 \\
\hline Aduça & 2 & “ & 3 & 3 & 6 \\
\hline Gurbiyet & 40 & “ & 116 & 104 & 220 \\
\hline Bağa & 14 & " & 39 & 42 & 61 \\
\hline Güre-i süfla & 9 & “ & 27 & 27 & 54 \\
\hline Güre-i ülya & 5 & " & 12 & 9 & 21 \\
\hline Başköy & 14 & “ & 32 & 37 & 69 \\
\hline Puruset & 8 & “ & 22 & 15 & 37 \\
\hline Cinçalet? & 11 & “ & 25 & 23 & 48 \\
\hline Lumikad & 8 & " & 19 & 16 & 35 \\
\hline Koklit & 4 & “ & 5 & 6 & 11 \\
\hline Güvamiçeret & 5 & “ & 14 & 11 & 25 \\
\hline Çilavur & 4 & “ & 12 & 9 & 21 \\
\hline Düzce & 16 & “ & 37 & 42 & 79 \\
\hline Kurudit & 9 & “ & 26 & 25 & 51 \\
\hline Omsal & 14 & “ & 42 & 46 & 87 \\
\hline Bucur & 16 & " & 40 & 48 & 88 \\
\hline Gevil & 9 & “ & 34 & 38 & 72 \\
\hline Gevil süfla & 2 & “ & 8 & 6 & 14 \\
\hline Arhova & 23 & “ & 39 & 43 & 82 \\
\hline Kamliyet & 1 & " & 3 & 4 & 7 \\
\hline Ereguna & 5 & " & 11 & 14 & 25 \\
\hline Cuvan & 11 & “ & 28 & 31 & 59 \\
\hline Derapen & 12 & " & 18 & 25 & 43 \\
\hline Dampel & 8 & “ & 12 & 12 & 24 \\
\hline Orci & 13 & “ & 33 & 29 & 62 \\
\hline Avana & 9 & " & 23 & 21 & 44 \\
\hline Toplam & 304 & & 766 & 794 & 1560 \\
\hline
\end{tabular}

Görüldüğü üzere Merkez Liva'ya bağlı Ardanuç nahiyesinde İslam mahallesinde 160 Türk, Ermeni mahallesinde 100 Ermeni yaşamaktadır. Köylerin tamamı Türklerden oluşmaktadır ve toplam nüfus 7809 kișiden ibarettir. Merkez Liva'ya bağlı Berta nahiyesi tamamen Türklerden oluşmaktadır ve nahiyede toplam 1122 kişi yaşamaktadır. Sirya nahiyesi tamamen Türklerden oluşan nahiyelerden birisidir ve 1528 kişilik nüfusa sahiptir. Şavşat kazasında 8603 Türk yaşamaktadır. Kazaya bağlı İmerhev nahiyesinde 7134 Gürcü İslam, Merya nahiyesinde 9539 Türk yaşamaktadır. Borçka kazasında ise 835 Gürcü İslam ve 250 Ermeni toplam 1085 kişi,

${ }^{22}$ TITEA: K.96 G.10 B.10-4. 
kazaya bağlı Maradid nahiyesinde 1333 Gürcü İslam, Maçahel nahiyesinde 1480 Gürcü İslam, Murgul nahiyesinde 1560 Gürcü İslam yaşamaktadır.

Elimizdeki son belge Şark Cephesi Kumandanı Kazım Karabekir tarafından Dâhiliye Vekâleti ve Erkân-1 Harbiye-i Umumiye Riyâseti'ne gönderilen 13.11.1921 (13.11.1337) tarihli Elviye-i Selâse bölgesinde oluşturulan idari teşkilatlanmaya ilişkindir ve teșkilatlanmada bazı düzenlemelere gidilmesi teklifini içermektedir ${ }^{23}$.

Kazım Karabekir, Ardahan ve Oltu havalisindeki seyahatinde yaptığı incelemeler sonrasında, Büyük Millet Meclisi tarafından kabul edilmiş olan teșkilata uygun olmakla beraber mahalli ihtiyaçlarla uygun bir șekilde faydalı olabilmesi için Elviye-i Selâse idare teşkilatında bazı düzenlemeler yapılması gerektiği sonucuna varmıştır. Bu düzenlemenin esasını Ardahan'ın kazaya dönüştürülmesi oluşturmaktadır ve bunun nedenlerini şu şekilde açıklamaktadır:

Merkez livayı teşkil eden Ardahan kasabası ancak dört- beş yüz nüfustan ibaret fevkalade harap ve mülhakatın geliriyle dahi memur maaşlarını ve sair zaruri ve resmi masraflarını koruyamayacak bir haldedir.

Bu halinden başka ticari, iktisadi ve sair faaliyetlere merkez olabilmesi imkânı yoktur. Diğer kazaların vaziyetleri de merkez livanın bunlardan birisine nakline müsait değildir. Çünkü Ardahan'a tabi kazaların her biri Kars'a mükemmel şoselerle bağlı ve kışın her mevsiminde dahi Kars ile bağlantıları mevcuttur. İktisadi, ticari, sosyal ilişkilerde Kars ve Oltu Erzurum'la alakalıdır. Hatta Kars'a en uzak mesafede bulunan ve 16161 nüfusu bulunan Posof Kazası'nın iktisadi ilişkileri de öncelikle Ahıska ve ikinci derecede Kars'ladır.

Ardahan Livası'nın bütün gelir kaynakları, Kars'a bağlı olması dolayısıyla maarif ve sair hususta doğu sınırının gerisinde Kars gibi önemli bir merkezin takviyesine imkân verilmesi ve Kars'ta meydana getirilecek kuvvetli bir teşkilat sayesinde birçok faydanın sağlanması mümkün olacaktır. Bu suretle geniş bir araziyi kapsayacak olan Kars ve Artvin livalarına bir mülkiye müfettişinin de tayin ve gönderilmesi idari faaliyetlerin de çoğalmasını kolaylaştırmış olacaktır.

Söz konusu yazıda, Elviye-i Selâse idari teşkilatında yapılması önerilen düzenlemeler bu şekilde gerekçelendirildikten sonra, Ardahan Livası'na halen tabi kazalardan Oltu daha çok ilgi ve ilişkisi dolayısıyla Erzurum'a, mülga Ardanuç kazası sınırının Ardahan'a kalan bölümünün Artvin

${ }^{23}$ TITEA K.96 G.29 B.29. 
Livası'na ve halen Erzurum Vilayeti'ne tabi Yusufeli kazasının da, coğrafi, ticari, örfi, sosyal durumlarına nazaran Artvin'e bağlanması ve Ardahan Livası'nın diğer kazalarının tamamen Kars'a bağlanması gerektiği belirtilmektedir.

Yusufeli kazasının Öğdem ve Erkinis (Demirkent) nahiyeleri esasen Artvin mülhakatından iken 93 sınırının ortaya çıkardığı zorunlulukla Erzurum'a bağlanmış olması ve Elviye-i Selâse'nin ele geçirilişini takiben adı geçen havali ahalisinin yakınlık, ticari ilişkiler dolayısıyla Artvin'e bağlanmaları hakkındaki bir mazbata ile Dâhiliye Vekâleti'ne ve Erzurum Vilayeti'ne de başvuruları, Yusufeli'nin Erzurum'dan daha çok Artvin ile ilişkisine bir gerekçe olarak gösterilmektedir.

Mahalli mutasarrıflıklar ve meclislerinde görüşülerek kararları alındığı takdirde arz edilen düzeltmenin daha ayrıntılı esaslara göre yapılmasının tabii olduğu ve havalideki teşkilat ve mesainin bir an evvel tayin ve intizarı elzem bulunduğundan gereği için bu teklifler arz edildiği belirtilerek yazıya son verilmektedir.

Resmi kayıt niteliğindeki bu belgeler, Artvin'in Türk Devleti'ne katıldığı ilk yıllardaki durumuna ilișkin bilgileri ilk elden bize vermesi açısından önem arz etmektedir. Artvin Livası nahiye teşkilatı üzerine bilgiler aynı zamanda Cumhuriyet hükümetinin mülki teşkilatlanması aşamaları ile ilgili bir fikir edinmemizi sağlamaktadır. Kazım Karabekir tarafından verilen rapor, bu günkü Artvin ili sınırlarının hangi esaslar üzerine oluştuğunu aydınlatmaktadır.

\section{KAYNAKÇA}

Ankara Üniversitesi Türk İnkılâp Tarihi Enstitüsü Arşivi (TíTEA) Kutu (K) 96 Gömlek (G)12 Belge (B)12

TITEA: K.96 G.10 B.10.

TITEA: K.96 G.10 B.10-2.

TITEA: K.96 G.10 B.10-3.

TITEA: K.96 G.10 B.10-4.

TITEA: K.96 G.10 B.10-5.

TITEA: K.96 G.10 B.10-6.

TITEA: K.96 G.10 B.10-7.

TITEA: K.96 G.13 B.13 (1-3). 
TITEA: K.96 G.29 B.29.

TBMM Kavanîn Mecmuası, Cilt 1, Ankara, 1943.

TBMM Zabut Ceridesi, Devre: 1 İçtima: 2, TBMM Matbaası, Ankara, 1958.

Yurt Ansiklopedisi, Cilt.2, Anadolu Yayıncılık, İstanbul, 1982.

Çadırcı, Prof.Dr. Musa, "Artvin Tarihine İlişkin Belgeler", Bizim Atabarı, Turizm Tanıtım Kültür Sanat Dergisi, sayı 18, Ankara, 2006.

Çadırcı, Prof.Dr. Musa, “Artvin Tarihine İlişkin Belgeler IF”, Bizim Ataban, Turizm Tanıtım Kültür Sanat Dergisi, sayı 19, Ankara, 2006.

Özdemir, Halit, Artvin Tarihi, II. Baskı, Artvin, 2002.

Ortaylı, Prof.Dr. İlber, "Çarlık Rusyası Yönetiminde Kars”, Osmanlı İmparatorluğu'nda İktisadi ve Sosyal Değişim, Makaleler I, Ankara, 2000. 